\title{
Distinct clinical and biological characteristics of acute myeloid leukemia with higher expression of long noncoding RNA KIAA0125
}

\author{
Yu-Hung Wang ${ }^{1,2}$ • Chien-Chin Lin ${ }^{1,2,3} \cdot$ Chia-Lang Hsu ${ }^{4} \cdot$ Sheng-Yu Hung ${ }^{5} \cdot$ Chi-Yuan Yao ${ }^{3,5} \cdot$ Sze-Hwei Lee ${ }^{1,6}$. \\ Cheng-Hong Tsai ${ }^{2} \cdot \mathrm{Hsin}-\mathrm{An} \mathrm{Hou}^{2} \cdot$ Wen-Chien $\mathrm{Chou}^{2,3} \cdot \mathrm{Hwei}^{2}$-Fang Tien ${ }^{2}$
}

Received: 9 September 2020 / Accepted: 18 November 2020 / Published online: 23 November 2020

(C) The Author(s) 2020

\begin{abstract}
Expression of long non-coding RNA KIAA0125 has been incorporated in various gene expression signatures for prognostic prediction in acute myeloid leukemia (AML) patients, yet its functions and clinical significance remain unclear. This study aimed to investigate the clinical and biological characteristics of AML bearing different levels of KIAA0125. We profiled KIAA0125 expression levels in bone marrow cells from 347 de novo AML patients and found higher KIAA0125 expression was closely associated with $R U N X 1$ mutation, but inversely correlated with $\mathrm{t}(8 ; 21)$ and $\mathrm{t}(15 ; 17)$ karyotypes. Among the 227 patients who received standard chemotherapy, those with higher KIAA0125 expression had a lower complete remission rate, shorter overall survival (OS) and disease-free survival (DFS) than those with lower expression. The prognostic significance was validated in both TCGA and GSE12417 cohorts. Subgroup analyses showed that higher KIAA0125 expression also predicted shorter DFS and OS in patients with normal karyotype or non-M3 AML. In multivariable analysis, higher KIAA0125 expression remained an adverse risk factor independent of age, WBC counts, karyotypes, and mutation patterns. Bioinformatics analyses revealed that higher KIAA0125 expression was associated with hematopoietic and leukemic stem cell signatures and ATP-binding cassette transporters, two predisposing factors for chemoresistance.
\end{abstract}

Keywords Long non-coding RNA $\cdot$ KIAA0125 Acute myeloid leukemia $\cdot$ Chemoresistance $\cdot$ Leukemic stem cell signatures

Yu-Hung Wang and Chien-Chin Lin contributed equally to this work.

Wen-Chien Chou

wchou@ntu.edu.tw

$\triangle$ Hwei-Fang Tien

hftien@ntu.edu.tw

1 Graduate Institute of Clinical Medicine, College of Medicine, National Taiwan University, Taipei, Taiwan

2 Division of Hematology, Department of Internal Medicine, National Taiwan University Hospital, No. 7, Chung-Shan S. Rd, Taipei City 10002, Taiwan

3 Department of Laboratory Medicine, National Taiwan University Hospital, No. 7, Chung-Shan S. Rd, Taipei City 10002, Taiwan

4 Department of Medical Research, National Taiwan University Hospital, Taipei, Taiwan

5 Division of Hematology, Department of Internal Medicine, National Taiwan University Hospital Yunlin Branch, Yunlin, Taiwan

6 Tai-Cheng Stem Cell Therapy Center, National Taiwan University, Taipei, Taiwan

\section{Introduction}

Long non-coding RNAs (lncRNAs) are non-protein coding RNAs that are longer than 200 nucleotides. Comparing to other classes of ncRNAs, lncRNAs exhibit a wide range of structures and functions [1]. Recently, lncRNAs have emerged as important regulators for gene expression via remodeling nuclear architecture, modulating mRNA stability and translation, and post-translational modifications [1-4]. Besides, some lncRNAs are dysregulated and harbor prognostic relevance in several types of cancers [5-8]. However, the roles of lncRNAs in tumorigenesis are still largely unknown.

In recent years, research on IncRNAs has increased drastically, and the results are robust. Although the functions of IncRNAs have not been elusive, recent studies suggested the expressions of lncRNAs could be used as prognostic factors, predictors of response, and potential therapeutic targets in acute leukemia [9-18]. Moreover, several gene expressionbased prognostic scores have been developed for better risk stratification of acute myeloid leukemia (AML) patients [19-24]. Among those high-risk genes, lncRNA gene 
KIAA0125 (also named as FAM30A), a hematopoietic stem cell gene localized on chromosome 14 , is unique because it is the only non-coding gene and is expressed in humans but not in mice (From the UniProt database, https://www.uniprot. org/uniprot/Q9NZY2). Additionally, KIAA0125 expression was integrated into a recently proposed 17 -gene stemness score, which could predict outcomes in AML patients [19].

This study aimed to investigate the association of KIAA0125 expression with clinical and biological characteristics in AML patients. We first profiled the expression levels of KIAA0125 in bone marrow (BM) cells from AML patients and normal controls and demonstrated that AML patients had higher KIAA0125 expression than normal controls. Higher expression of KIAA0125 was associated with distinct clinical and biological characteristics and served as an independent poor prognostic biomarker for AML patients in ours and two other publicly annotated cohorts. Further bioinformatics analyses showed that higher expression of KIAA0125 in AML was closely associated with hematopoietic stem cell (HSC) and leukemic stem cell (LSC) signatures and several important ATP-binding cassette transporters ( $\mathrm{ABC}$ transporters); these factors are regarded responsible for chemoresistance in AML. Further functional studies are needed to unravel its underlying mechanism and pathogenetic role in AML.

\section{Materials and methods}

\section{Patients}

We recruited 347 adult patients with de novo AML diagnosed in the National Taiwan University Hospital (NTUH) from 1996 to 2011 who had enough cryopreserved BM cells for tests. The diagnoses were based on the French-AmericanBritish (FAB) and the 2016 World Health Organization classifications [25, 26]. Among them, 227 patients received standard chemotherapy. Non M3 (acute promyelocytic leukemia, APL) patients received idarubicin $12 \mathrm{mg} / \mathrm{m}^{2}$ per day days $1-3$ and cytarabine $100 \mathrm{mg} / \mathrm{m}^{2}$ per day days $1-7$, and then consolidation chemotherapy with 2-4 courses of high-dose cytarabine $2000 \mathrm{mg} / \mathrm{m}^{2} \mathrm{q} 12 \mathrm{~h}$ for total 8 doses, with or without an anthracycline (Idarubicin or Mitoxantrone), after achieving complete remission (CR) as described previously [27]. APL patients received concurrent all-trans retinoic acid and chemotherapy. The remaining 120 patients received supportive care and/or reduced-intensity anti-leukemia therapy due to underlying comorbidities or based on the decision of the physicians or patients. BM samples from 30 healthy donors of hematopoietic stem cell transplantation (HSCT) were collected as normal controls. This study was approved by the Research Ethics Committee of NTUH with informed consent obtained from all participants.
Microarray and genetic alteration analysis

We profiled the global gene expression of BM mononuclear cells from 347 AML patients and 30 healthy transplant donors by Affymetrix GeneChip Human Transcriptome Array 2.0 as described previously $[21,28,29]$. The raw and normalized microarray data reported in this article have been deposited in the Gene Expression Omnibus database (accession number GSE68469 and GSE71014) [21, 28, 29]. For external validation, we analyzed two publicly annotated datasets, the microarray dataset of GSE12417-GPL96 cohort, which includes the gene expression profile of 163 patients with cytogenetically normal AML, and the RNAseq dataset of the TCGA cohort $(n=186)$ [20,30]. Cytogenetic analyses were performed and interpreted as described previously [31]. We also analyzed the mutation statuses of 17 myeloid-relevant genes, including ASXL1, IDH1, IDH2, TET2, DNMT3A, FLT3-ITD, FLT3-TKD, KIT, NRAS, KRAS, RUNX1, MLL/PTD, CEBPA, NPM1, PTPN11, TP53, and WT1 by Sanger sequencing as previously described [27, 28, 31-34].

\section{Analysis of gene expression in next-generation se- quencing datasets}

We analyzed gene expression data of 141 AML samples profiled with Illumina Genome Analyzer RNA Sequencing in the TCGA database [30] to investigate the absolute gene expression levels.

\section{Gene set enrichment analysis}

The preranked Gene Set Enrichment Analysis (GSEA) implemented by $\mathrm{R}$ package clusterProfiler was performed using the stem cell-related gene sets from the MSigDB databases. The genes were ranked based on the Spearman's correlation coefficient between the given gene and KIAA0125.

\section{Statistical analysis}

We used the Mann-Whitney U test and ANOVA test, where appropriate, to compare continuous variables and medians/ means of distributions. The Fisher exact test or the $\chi^{2}$ test was performed to examine the difference in discrete variables, including gender, cytogenetic changes, and genetic alterations between patients with lower and higher KIAA0125 expression. Overall survival (OS) was the duration from the date of initial diagnosis to the time of last follow-up or death from any cause, whichever occurred first. Disease-free survival (DFS) was the duration from the date of attaining a leukemia-free state until the date of AML relapse or death from any cause, whichever occurred first. The survival prediction power of KIAA0125 expression was evaluated by both the log-rank test and the univariate Cox proportional hazards model. We 
plotted the survival curves with Kaplan-Meier analysis and calculated the statistical significance with the log-rank test. To find the optimal cutoff for separating patient groups, we used maximally selected rank statistics implemented in the maxstat $\mathrm{R}$ package. The Cox proportional hazards model was used in multivariable regression analysis. $P$ values $<$ 0.05 were considered statistically significant. All statistical analyses were performed with BRB-ArrayTools (version 4.5.1; Biometric Research Branch, National Cancer Institute, Rockville, MD), and IBM SPSS Statistics 23 for Windows.

\section{Results}

The median age of the 347 AML patients was 57 years. Among the 331 patients who had cytogenetic data at diagnosis, $165(49.8 \%)$ had clonal chromosomal abnormalities. Sixty patients (18.1\%) had favorable cytogenetics; 223 (67.2\%), intermediate-risk cytogenetics; and $14.8 \%$ unfavorable cytogenetics (Supplement Table 1) based on the refined British Medical Research Council (MRC) classification [35]. The clinical and laboratory characteristics of these patients at diagnosis are summarized in Table 1.

\section{Comparison of clinical characteristics and genetic alterations between patients with higher and lower KIAA0125 expression}

The distribution of KIAA0125 expression of 347 AML patients is shown with dot plots in Supplement Fig. 1. We first compared the BM KIAA0125 expression between the 30 healthy controls and 347 AML patients. The expression of KIAA0125 was significantly higher in AML samples than healthy controls ( $p<0.001$, Fig. 1a). Then, the 347 AML patients were divided into two groups by the median value of the KIAA0125 expression. The comparison of clinical and laboratory features between the two groups is shown in Table 1 . The higher-KIAA0125 group had higher circulating blasts at diagnosis $(p=0.021)$ and higher incidence of FLT3-ITD in the absence of NPM1 mutation (NPM1-/FLT3-ITD+) $(p=$ 0.002 ) and $R U N X 1$ mutation ( $p=0.034)$, but lower incidence of $\mathrm{t}(8 ; 21)$ and $\mathrm{t}(15 ; 17)$ (both $p<0.001)$, compared with the lower-KIAA0125 group (Table 1). From another perspective, patients with $\mathrm{t}(8 ; 21)$ or $\mathrm{t}(15 ; 17)$ had lower KIAA0125 expression, whereas those with $R U N X 1$ mutation, $A S X L 1$ mutation, NPM1-/FLT3-ITD+, or unfavorable karyotypes had higher expression of KIAA0125 ( $\mathrm{F}=15.124, p<0.001$, Fig. $1 \mathrm{~b}$, Supplement Table 1 and Supplement Table 2). Furthermore, the association of higher-KIAA0125 with lower frequencies of $\mathrm{t}(8 ; 21)$ and $\mathrm{t}(15 ; 17)$ was observed in both the NTUH cohort (both $p<0.001$, Supplement Table 3 ) and TCGA cohort ( $p=$ 0.006 and $p<0.001$, respectively, Supplement Table 3). The higher-KIAA0125 patients more frequently had FLT3-ITD $(p=0.048)$ and mutations in DNMT3A $(p=0.015)$ and RUNXI ( $p=0.034)$ (Supplement Table 4). Compatible with this finding, patients with DNMT3A or RUNX1 mutation had higher KIAA0125 expression than those without the mutation ( $p=0.019$ and 0.045, respectively, Supplement Fig. 2). Similarly, there was close association between higher KIAA0125 expression and DNMT3A $(p=0.001)$ and RUNXI mutations $(p=0.017)$ in the TCGA cohort (Supplement Table 5). Among the 227 patients who received standard chemotherapy, $165(72.7 \%)$ patients attained a complete remission (CR), while $42(18.5 \%)$ patients had primary refractory diseases. Notably, the patients with higher KIAA0125 expression had a lower CR rate $(61.2 \%$ vs. $84.7 \%, p<0.001)$ than those with lower expression. In accordance with this finding, the patients who achieved CR after induction chemotherapy had lower expression of BM KIAA0125 at diagnosis than those who did not $(p<0.001$, Fig. 1c).

\section{The impacts of the KIAA0125 expression on OS and DFS}

Next, we divided patients into two groups with high and low KIAA0125 expression with cut points determined by the maximally selected rank statistics (7.72 in the NTUH cohort, 8.56 in the TCGA cohort, and 9.71 in GSE12417 cohort, respectively, Supplement Fig. 3). As expected, patients with higher KIAA0125 expression had an inferior DFS and OS than those with lower expression, no matter whether the survival was censored on the day of hematopoietic stem cell transplantation (HSCT) (median, 3.2 months vs. 31.7 months, $p<0.001$; and 17 months vs. not reached (NR), $p<0.001$, respectively; Fig. $2 \mathrm{a}$ and $\mathrm{b})$ or not $(p<0.001$ and $p<0.001$, respectively; Supplement Fig. 4a and 4b). Subgroup analyses showed that the prognostic significance of KIAA0125 expression for DFS and OS remained valid in both non-APL and normal karyotype patients (Figs. $2 \mathrm{c}$ and d).

In multivariable analysis, we included clinically relevant parameters and variables with a $p$ value $<0.05$ in univariate Cox regression analysis (Supplement Table 4) as covariates, including age, white blood cell counts at diagnosis, karyotypes, mutation statuses of NPM1/FLT3-ITD, $C E B P A^{\text {double mutations }}, R U N X 1, M L L-P T D$, and TP53, and KIAA0125 expression. Higher KIAA0125 expression, either divided by the selected cut-point (Table 2) or calculated as continuous values (Supplement Table 5), was an independent adverse prognostic factor for DFS $(p<0.001$ and $p<0.001$, respectively) and $\operatorname{OS}(p=0.003$ and $p=$ 0.001 , respectively). To verify the prognostication power of the KIAA0125 expression, we analyzed the expression of KIAA0125 and its prognostic significance in the TCGA cohort and the GSE12417-GPL96 cohort. Consistent with the findings in the NTUH cohort, patients with higher KIAA0125 expressions had a significantly shorter OS 
Table 1 Comparison of clinical and laboratory features between AML patients with lower and higher BM KIAA0125 expression

\begin{tabular}{|c|c|c|c|c|}
\hline Clinical characters & Total $(N=347)$ & $\begin{array}{l}\text { High KIAA0125 } \\
(n=174)\end{array}$ & $\begin{array}{l}\text { Low KIAA0125 } \\
(n=173)\end{array}$ & $P$ value \\
\hline Sex & & & & 0.174 \\
\hline Male & 196 & 92 & 104 & \\
\hline Female & 151 & 82 & 69 & \\
\hline Age* $^{*}$ & & $57(15-91)$ & $58(18-90)$ & 0.830 \\
\hline \multicolumn{5}{|l|}{ Laboratory data* } \\
\hline WBC, $X 10^{9} / \mathrm{L}$ & $21.9(0.38-423)$ & $21.4(0.38-417.5)$ & $22.38(0.65-423.0)$ & 0.872 \\
\hline $\mathrm{Hb}, \mathrm{g} / \mathrm{dL}$ & $8.1(3.3-16.2)$ & $8.1(3.3-13.2)$ & $8.1(3.7-16.2)$ & 0.959 \\
\hline Platelet, X $10^{9} / \mathrm{L}$ & $45(2-655)$ & $54(6-455)$ & $41(2-655)$ & 0.060 \\
\hline Blast, $X 10^{9} / \mathrm{L}$ & $9.1(0-369.1)$ & $12.3(0-345.9)$ & $5.7(0-369.1)$ & 0.021 \\
\hline LDH (U/L) & $\begin{array}{l}917 \\
\quad(202-13,130)\end{array}$ & $892.5(242-7734)$ & $925(202-13,130)$ & 0.787 \\
\hline \multicolumn{5}{|l|}{ Risk groups } \\
\hline$t(8 ; 21)$ & 24 & $0(0)$ & $24(14.3)$ & $<0.001$ \\
\hline $\mathbf{t}(15 ; 17)$ & 27 & $3(1.8)$ & $24(14.3)$ & $<0.001$ \\
\hline $\operatorname{inv}(16)$ & 9 & $6(3.7)$ & $3(1.8)$ & 0.332 \\
\hline$C E B P A^{\text {double }}$ & 27 & $13(48.1)$ & $14(51.9)$ & 0.829 \\
\hline NPM1+/FLT3-ITD- & 57 & $32(18.4)$ & $25(14.5)$ & 0.385 \\
\hline NPM1-/FLT3-ITD+ & 19 & $3(1.7)$ & $16(9.2)$ & 0.002 \\
\hline$R U N X 1$ & 50 & $32(64)$ & $18(36)$ & 0.034 \\
\hline$A S X L 1$ & 52 & $26(50)$ & $26(50)$ & 0.982 \\
\hline $\begin{array}{l}\text { Unfavorable } \\
\text { karyotypes } t \dagger\end{array}$ & 49 & $30(18.3)$ & $19(11.3)$ & 0.089 \\
\hline $\begin{array}{l}\text { Induction response, } \mathbf{n} \\
(\%)\end{array}$ & 227 & 116 & 111 & \\
\hline CR & $165(72.7)$ & $71(61.2)$ & $94(84.7)$ & $<0.001$ \\
\hline PR & $5(2.2)$ & $4(3.4)$ & $1(0.9)$ & 0.191 \\
\hline Refractory & $42(18.5)$ & $33(28.4)$ & $9(8.1)$ & $<0.001$ \\
\hline Induction death & $15(6.6)$ & $8(6.9)$ & $7(6.3)$ & 0.858 \\
\hline Relapse (\%) & $72(31.7)$ & $42(36.2)$ & $30(27.0)$ & 0.137 \\
\hline
\end{tabular}

Abbreviations: $C R$ complete remission, $H b$ hemoglobin, $H S C T$ allogeneic hematopoietic stem cell transplantation, $L D H$ lactate dehydrogenase, $P R$ partial remission

* Median (range)

$\dagger$ Cytogenetic data at diagnosis were available in 332 patients, including 168 with lower KIAA0125 expression and 164 with higher KIAA0125 expression

$\$$ Based on the refined Medical research Council (MRC) classification
(9.2 months vs. 20.3 months, $p<0.001$, and 7.4 months vs. 33.3 months, $p<0.001$, respectively, Figs. 2e and f) than those with lower KIAA0125 expression in the two external validation cohorts.

\section{Biological impacts of KIAA0125 in AML}

To gain biological insights into the underlying mechanism of unfavorable prognosis related to KIAA0125 overexpression, we investigated the genes whose expression is strongly correlated with that of KIAA0125. Since KIAA0125 was reported as an LSC marker [19], we curated several published HSC and LSC signatures from different studies
[36-38]. GSEA showed HSC and LSC signatures were all significantly enriched in the patients with higher KIAA0125 expression in both the NTUH and TCGA cohorts (both $p<0.001$, Fig. 3a). We next checked the leading-edge genes whose expression levels were most positively correlated to KIAA0125 expression in both NTUH and TCGA cohorts. Among them, SPINK2, MAP7, HOPX, MMRN1, DNMT3B, TCF4, SLC38A1, DOCK1, ARHGAP22, MN1, and 4 genes in the ATPbinding cassette (ABC) superfamily ( $A B C G 1, A B C A 2$, $A B C B 1$, and $A B C C 1$ ) have been reported to be associated with poor prognosis or chemoresistance in AML (Fig. 3b and Table 3) [19, 39-58]. 
Fig. 1 Dot plots depicting expression levels of KIAA0125 in healthy controls and various AML subgroups. a Patients with AML had significantly higher expression of KIAA0125 than healthy controls; $\mathbf{b}$ patients with karyotypes of $\mathrm{t}(8 ; 21)$ or $\mathrm{t}(15 ; 17)$ had significantly lower expression of KIAA0125 than any other subgroups while patients with NPM1-/FLT3-ITD+, $R U N X 1, A S X L 1$, or unfavorable karyotypes had highest expression among all subgroups; and $\mathbf{c}$ patients who achieved CR after induction chemotherapy had lower expression of BM KIAA0125 at diagnosis than those who did not. *Based on the refined Medical research Council (MRC) classification a

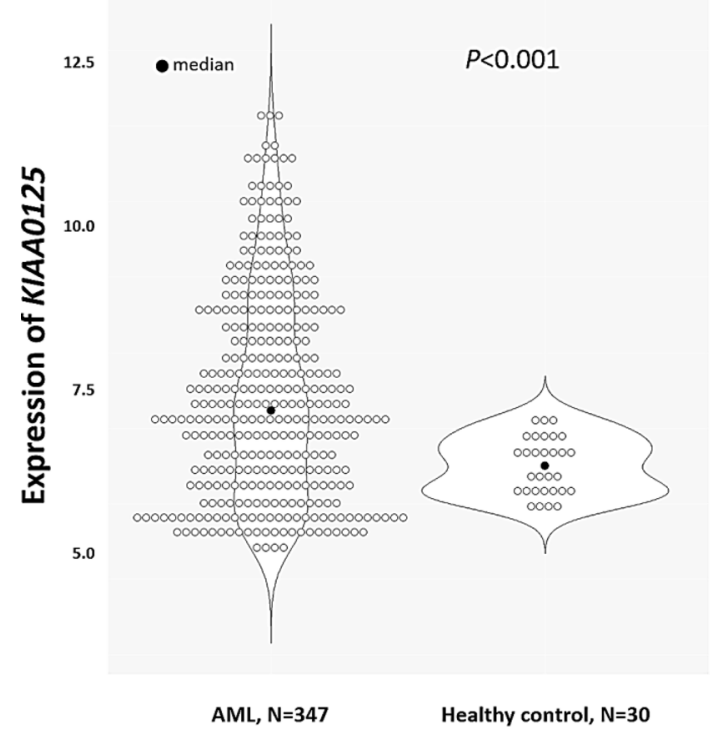

b

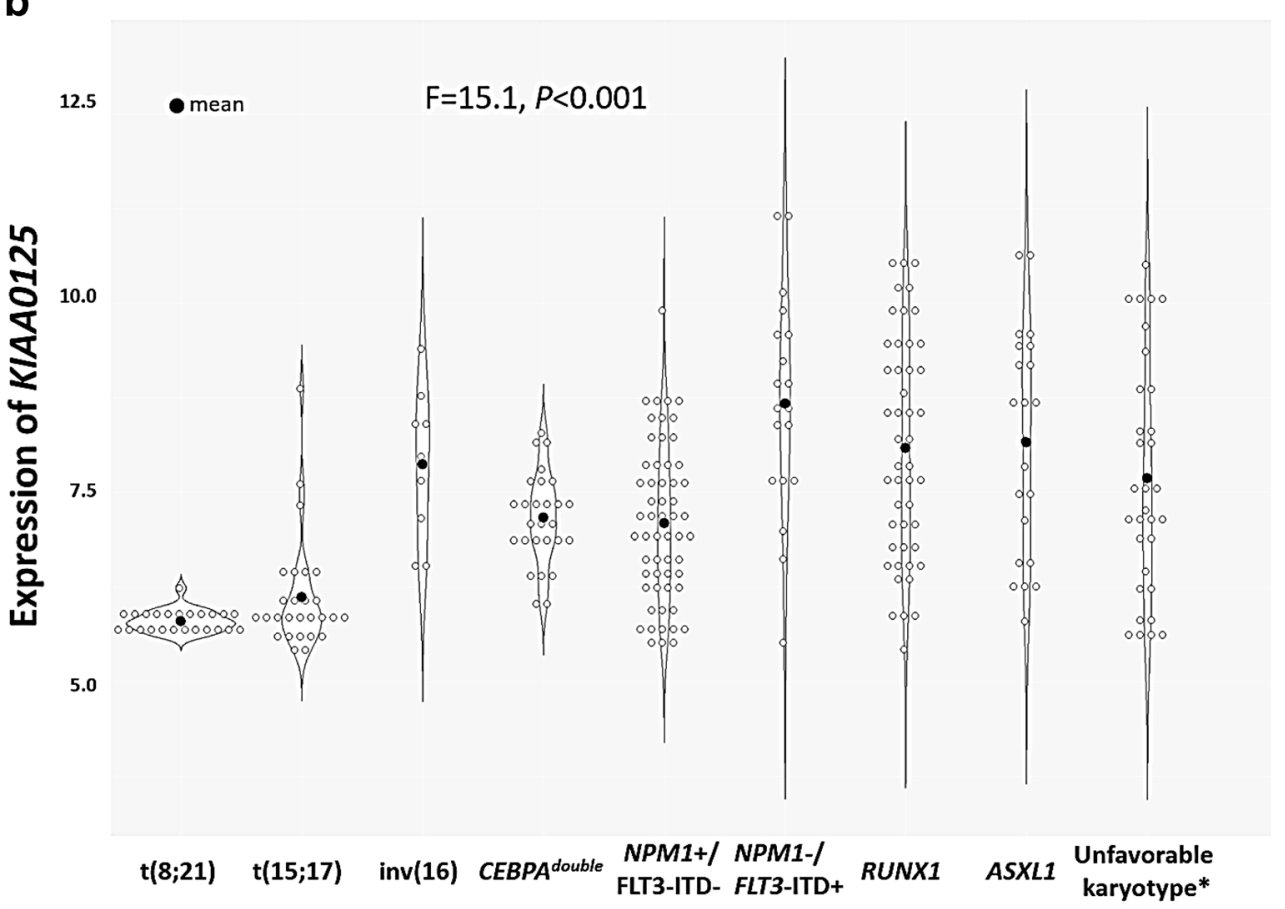

C

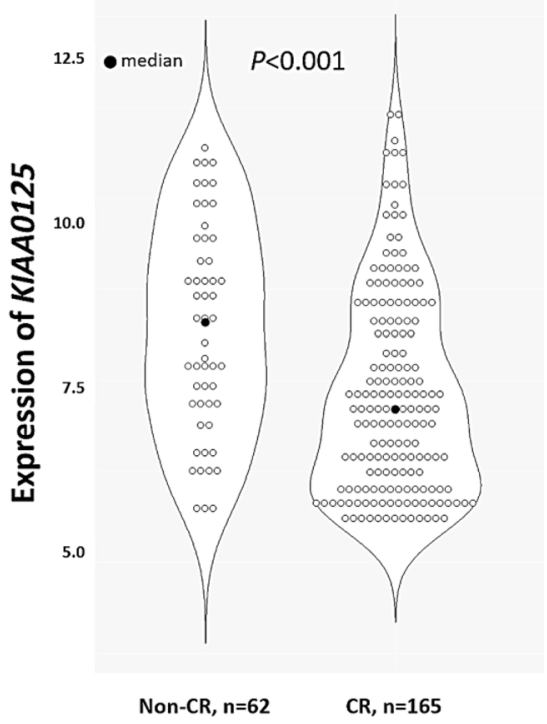

\section{Discussion}

AML cells have abnormal genetic background, either mutations or aberrant expression of specific genes. In recent years, several gene expression scores have been proposed for prognostic prediction of AML patients. We previously developed a 11-gene mRNA expression signature, including $A I F 1 L$, CXCR7, DNTT, GPR56, H1F0, IFITM3, KIAA0125, MX1, $S T A B 1, T M 4 S F 1$, and TNS3, for prognostication in AML patients [21]. Another group built a six-gene leukemia stem cell (LSC) score with the incorporation of DNMT3B, GPR56, 
a

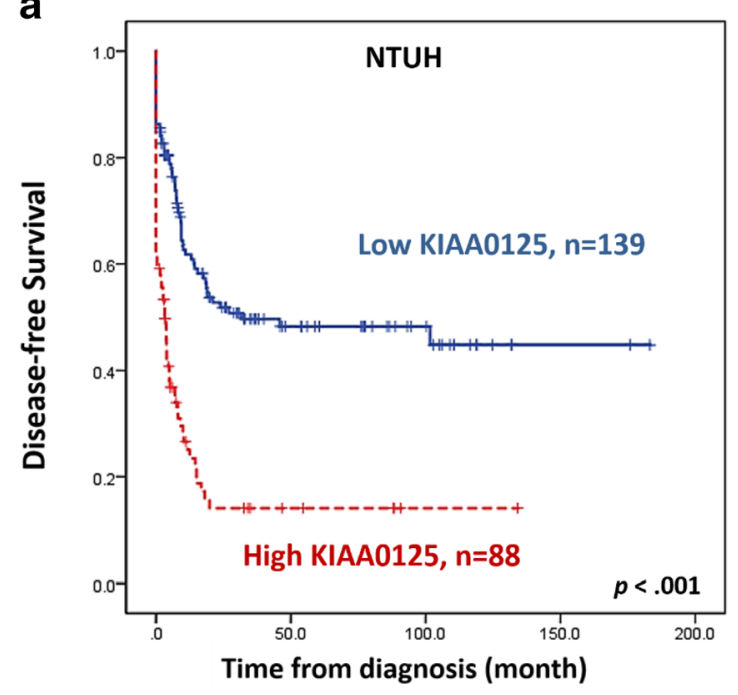

C

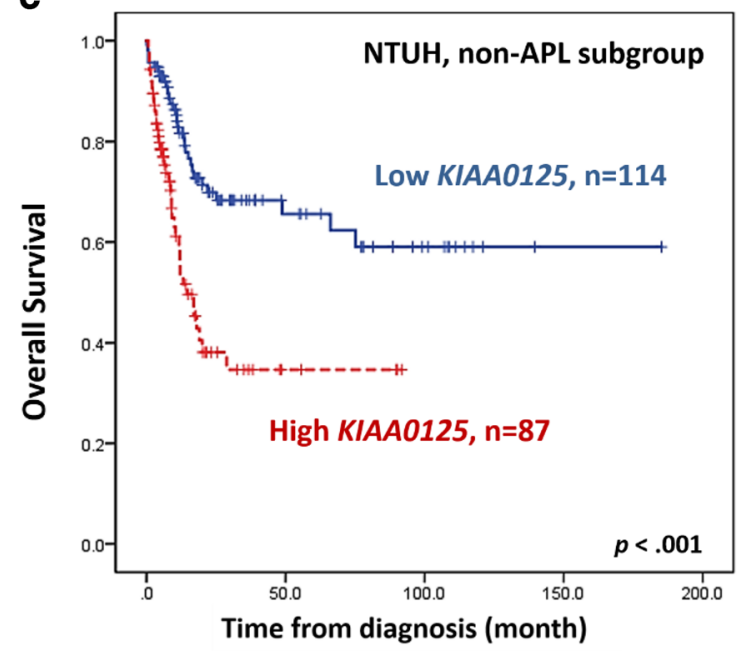

e

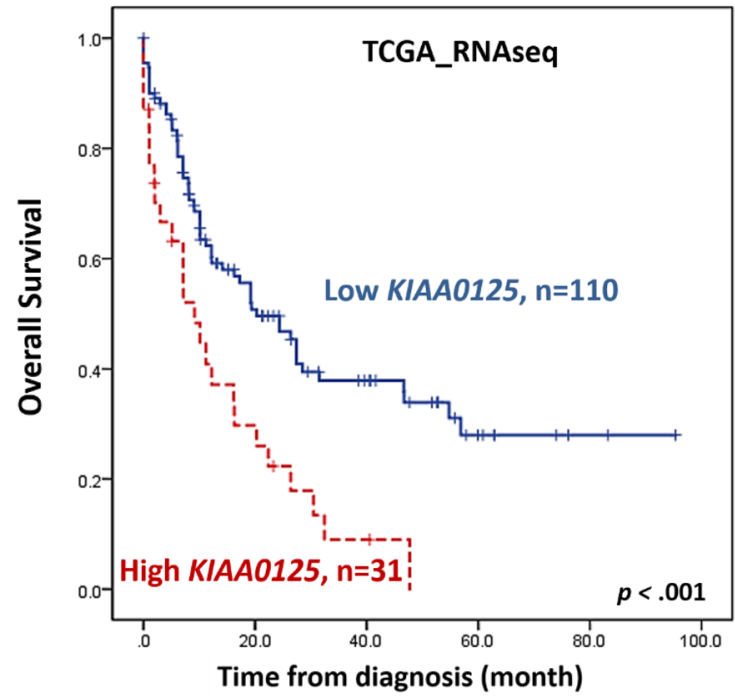

Fig. 2 Kaplan-Meier survival curves stratified by expression of KIAA0125. DFS a and OS b of the 227 AML patients receiving standard chemotherapy in the NTUH cohort; OS of 201 non-APL patients c and 110 cytogenetically normal AML patients $\mathbf{d}$ who received standard

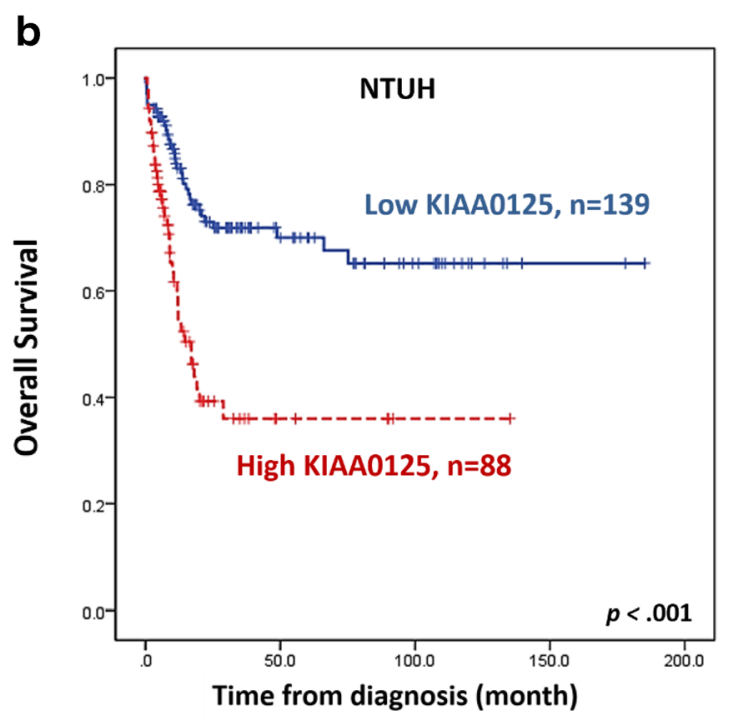

d

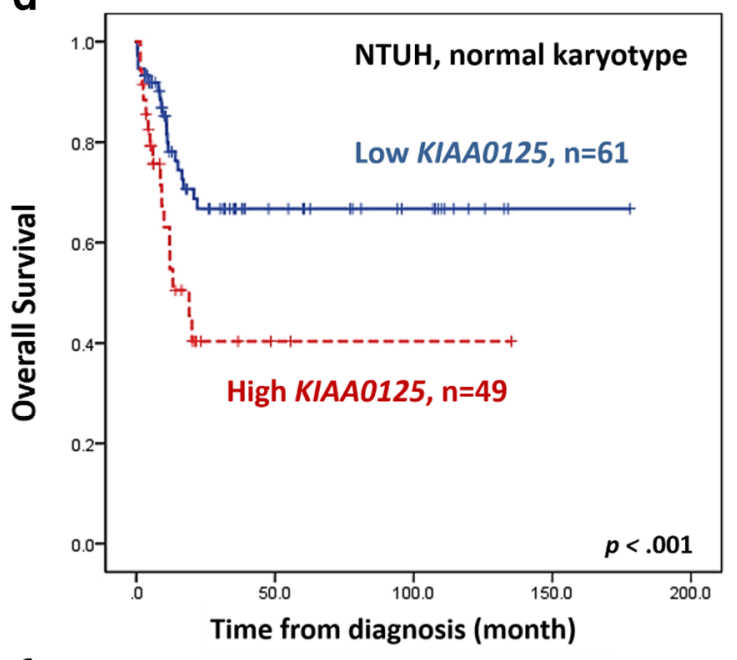

f

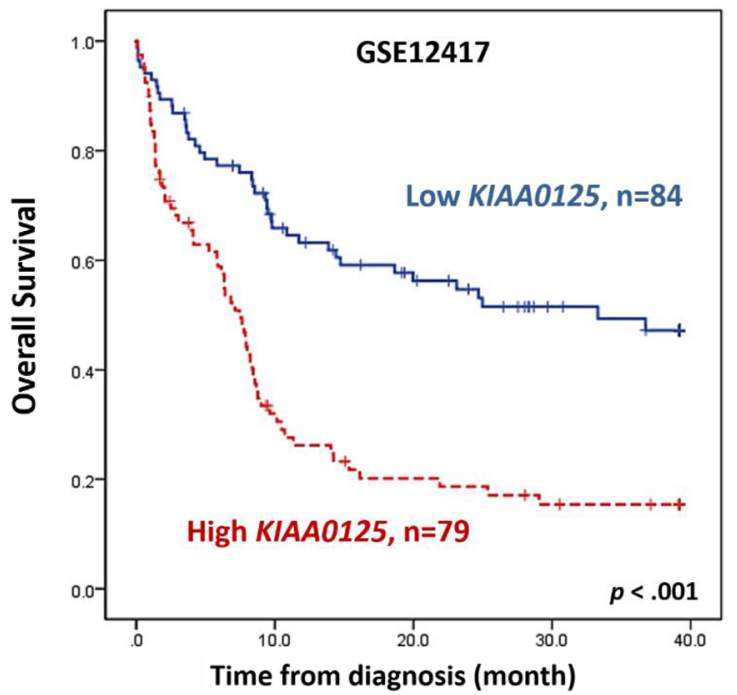

treatment in the NTUH cohort; and OS of 141 patients in the TCGA cohort e and GSE12417-GPL96 cohort f. Patients with higher KIAA0125 expression had worse clinical outcomes than those with lower expression 
Table 2 Multivariable analysis for DFS and OS in 227 AML patients who received standard intensive chemotherapy

\begin{tabular}{|c|c|c|c|c|c|c|c|c|}
\hline \multirow[b]{3}{*}{ Variable } & \multicolumn{4}{|l|}{ DFS } & \multicolumn{4}{|l|}{ OS } \\
\hline & \multicolumn{4}{|c|}{$95 \% \mathrm{CI}$} & \multicolumn{4}{|c|}{$95 \% \mathrm{CI}$} \\
\hline & HR & Lower & Upper & $P$ & HR & Lower & Upper & $P$ \\
\hline Age* & 1.007 & 0.995 & 1.019 & 0.253 & 1.030 & 1.014 & 1.047 & $<0.001$ \\
\hline $\mathrm{WBC}^{*}$ & 1.004 & 1.002 & 1.007 & 0.001 & 1.005 & 1.001 & 1.008 & 0.012 \\
\hline Karyotype $\dagger$ & 1.610 & 1.201 & 2.160 & 0.001 & 1.706 & 1.158 & 2.513 & 0.007 \\
\hline NPM1/FLT3-ITD & 0.601 & 0.332 & 1.089 & 0.093 & 0.895 & 0.443 & 1.808 & 0.757 \\
\hline$C E B P A^{\text {double }}$ & 0.598 & 0.286 & 1.252 & 0.173 & 0.451 & 0.137 & 1.488 & 0.191 \\
\hline$R U N X 1$ & 1.532 & 0.875 & 2.683 & 0.136 & 1.432 & 0.726 & 2.821 & 0.300 \\
\hline$M L L-\mathrm{PTD}$ & 2.706 & 1.263 & 5.799 & 0.010 & 2.882 & 1.077 & 7.710 & 0.035 \\
\hline TP53 & 1.918 & 0.697 & 5.283 & 0.207 & 3.030 & 0.956 & 9.608 & 0.060 \\
\hline Higher KIAA0125 expression§ & 2.300 & 1.569 & 3.371 & $<0.001$ & 2.188 & 1.317 & 3.636 & 0.003 \\
\hline
\end{tabular}

$p$ values $<.05$ are considered statistically significant

Abbreviations: HR, hazard ratios; CI, confidence interval

*As continuous variable

$\dagger$ Unfavorable cytogenetics versus others. The classification of favorable, intermediate and unfavorable cytogenetics is based on the refined Medical Research Council (MRC) classification [27]. Favorable: t(15;17)(q22;q21), $\mathrm{t}(8 ; 21)(\mathrm{q} 22 ; \mathrm{q} 22)$, and inv.(16)(p13q22)/t(16;16)(p13;q22); unfavorable: abn(3q) (excluding $\mathrm{t}(3 ; 5)(\mathrm{q} 25 ; \mathrm{q} 34)$ ), inv.(3)(q21q26)/t(3;3)(q21;q26), add(5q)/del(5q), -5, -7, $\operatorname{add}(7 \mathrm{q}) / \operatorname{del}(7 \mathrm{q}), \mathrm{t}(6 ; 11)(\mathrm{q} 27 ; \mathrm{q} 23)$, $\mathrm{t}(10 ; 11)(\mathrm{p} 1113 ; \mathrm{q} 23)$, other $\mathrm{t}(11 \mathrm{q} 23)$ (excluding $\mathrm{t}(9 ; 11)(\mathrm{p} 21 \sim 22 ; \mathrm{q} 23)$ and $\mathrm{t}(11 ; 19)(\mathrm{q} 23 ; \mathrm{p} 13)), \mathrm{t}(9 ; 22)(\mathrm{q} 34 ; \mathrm{q} 11)$, -17 , and abn(17p); and intermediate: entities not classified as favorable or adverse. Seven patients without chromosome data were not included in the analysis

$\ddagger N P M 1+/ F L T 3-I T D-$ versus other subtypes

§High vs. low expression of KIAA0125
60]. Nonetheless, the clinical relevancy and biological role of KIAA0125 in tumorigenesis were still largely unclear.

In this study, we found that the expression level of KIAA0125 in BM was significantly higher in AML patients than normal HSC transplant donors. The expression of KIAA0125 was lower in patients with $\mathrm{t}(8 ; 21)$ and $\mathrm{t}(15 ; 17)$ which are associated with more differentiated AML subtypes, but higher in patients with $R U N X 1, A S X L 1$ mutations, NPM1-/FLT3-ITD+ or poor-risk karyotypes. It is interesting that the expression of KIAA0125 was high in patients with RUNX1 mutation but modest in those with $R U N X 1 /$ $R U N X 1 T 1$ fusion consisting with the fact that AML patients with a RUNX1 mutation usually had poor outcomes while those with RUNX1/RUNX1T1 fusion had favorable prognosis. Recently, Hornung et al. identified that expression of CD109, $H O P X$, and KIAA0125 genes might be responsible for inferior survival in AML patients with RUNX1 mutations but, on the other hand, better outcome in RUNX1/RUNX1T1 fusion through a newly proposed statistical tool "mediation analysis." The three genes' expression levels were significantly higher in patients with RUNX1 mutant but lower in those with $R U N X 1 / R U N X 1 T 1$ fusion [61]. Intriguingly, though there has been no study showing direct evidence that $R U N X 1$ binds to $K I A A 0125$ till now in the literature, $R U N X 1$ has been reported to bind to TGTGG core sequences as a heterodimer of RUNX1 and $\mathrm{CBF} \beta$ [62]. We downloaded and retrieved the DNA sequence of KIAA0125 from the UCSC Genome Browser (https://genome.ucsc.edu/) and found several sequences of TGTGG (Supplement Table 8) within the 3000 bp upstream sequence, which might be the potential binding sites of $R U N X 1$. Further studies are needed to explore the effect of the possible interaction between RUNX1 domain and KIAA0125.

Bioinformatics of the present study showed highly significant association of KIAA0125 expression with stem cell signatures, either HSC or LSC. We found that expressions of SPINK2, MAP7, HOPX, MMRN1, DNMT3B, TCF4, SLC38A1, DOCK1, ARHGAP22, MN1, and 4 genes in the ATP-binding cassette (ABC) superfamily ( $A B C G 1, A B C A 2$, $A B C B 1$, and $A B C C 1$ ), which have been reported to be associated with poor prognosis or chemoresistance in AML, were positively correlated to higher expression of KIAA0125 (Fig. $3 \mathrm{~b}$ and Table 3). HOPX, DOCK1, DNMT3B, MMRN1, and $A R H G A P 22$ genes were reported as important leukemia stem cell markers [19, 42, 43, 45, 50, 63]. Higher SPINK2 expression was associated with poor prognosis in adult and pediatric AML [39, 40]. TCF4 expression could predict outcome in RUNX1-mutated and translocated AML [47, 48]. MN1 overexpression could induce AML in mice and predict ATRA resistance in human $\mathrm{AML}$ patients [51, 52]. Current 
a

\section{NTUH}

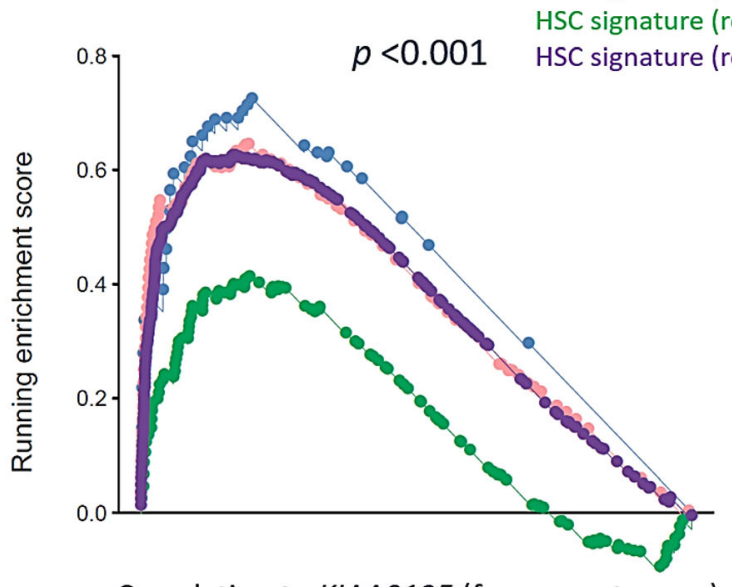

Correlation to KIAA0125 (from pos. to neg.)

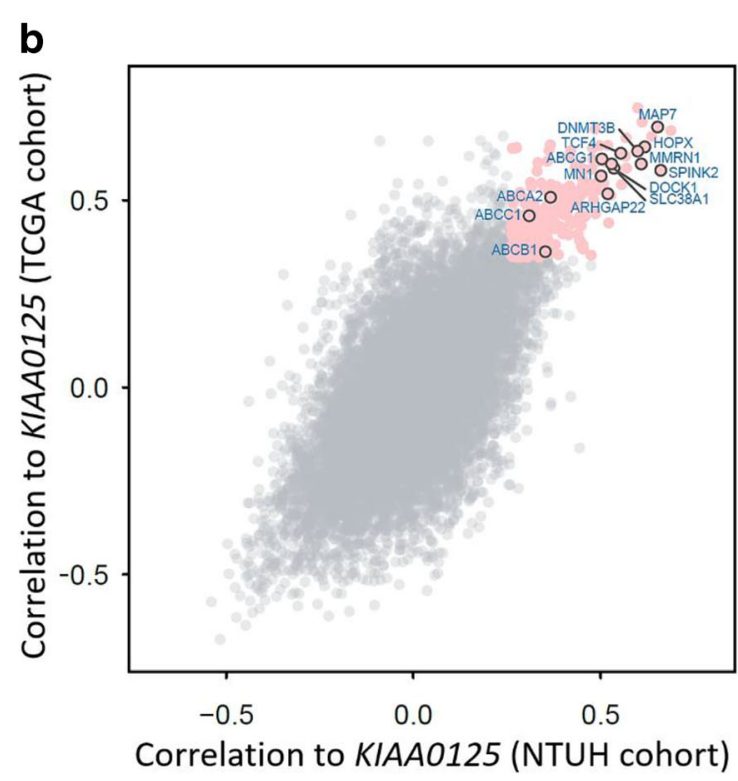

Fig. 3 GSEA enrichment plots of HSC and LSC signatures and scatter plot of genes positively associated with higher KIAA0125 expression. a GSEA enrichment plots show positive association of higher KIAA0125 expression with HSC and LSC signatures curated from several published reports in both the NTUH and TCGA cohorts; b the scatter plot reveals the genes strongly correlated to KIAA0125

knowledge about the association between theses KIAA0125correlated genes and AML is summarized in Table 3.

Interestingly, the expression levels of several $\mathrm{ABC}$ transporter genes, including $A B C A 2, A B C B 1, A B C C 1$, and $A B C G 1$, were also significantly higher in AML patients with higher KIAA0125 expression. The ABC transporter family consists of 48 proteins in subfamilies designated $A$ to $G$ and some of them are known to be associated with multidrug resistance via ATP-dependent drug efflux [53, 54, 57]. $A B C B 1$, $A B C C 1$, and $A B C G 1$ were reported to be responsible for chemoresistance in AML $[53,56]$. The translational expression of $A B C A 2$ was shown to be a prognostic marker for drug

\section{TCGA}

$p<0.001$

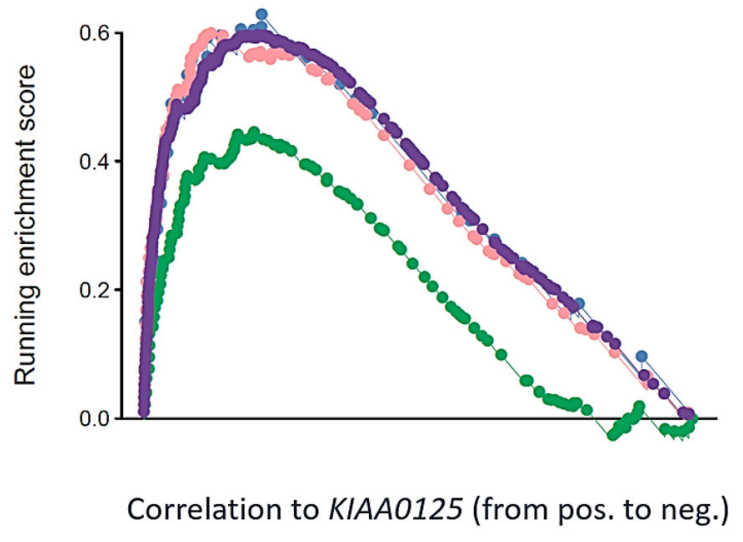

Correlation to KIAA0125 (from pos. to neg.)

expression in both the NTUH and TCGA cohorts (pink). The correlation measurement is based on the Spearman's correlation coefficient between the given gene and KIAA0125. The strongly correlated genes are defined as their correlation values at top 5\% of all genes in both cohorts

resistance in pediatric acute lymphoblastic leukemia [55, 58]. The underlying mechanistic basis of the high correlation of these 4 genes to the expression of KIAA0125 warrants further studies.

This study's limitations lie in its retrospective nature and, crucially, the unsorted BM sample, as many cells in BM may be differentiated cells of myeloid and erythroid lineages. The study could have been more informative if we could profile KIAA0125 expression of healthy CD34 + CD38- HSCs and more mature progenitors (CD34 + CD38- and CD34$\mathrm{CD} 117+$, respectively) and compare those with leukemia blasts. Moreover, the putative oncogenic role of KIAA0125 
Table 3 Summary of the biological functions of the KIAA0125-associated genes that have been reported to be associated with prognosis or drug resistance in AML patients and their correlation values with KIAA0125 in ours and the TCGA cohorts

\begin{tabular}{|c|c|c|c|c|c|}
\hline \multirow{3}{*}{$\begin{array}{l}\text { Genes } \\
\text { SPINK2 }\end{array}$} & \multicolumn{4}{|c|}{ Correlation coefficient ( $p$ value) } & \multirow{3}{*}{$\begin{array}{l}\text { Association with leukemia } \\
\text { Serine Peptidase Inhibitor; upregulation is } \\
\text { associated with poor outcomes in adult } \\
\text { patients with AML [30]; integrated into a } \\
\text { 6-gene LSC score to identifies high risk pedi- } \\
\text { atric AML [31] }\end{array}$} \\
\hline & \multicolumn{2}{|c|}{ NTUH } & \multicolumn{2}{|l|}{ TCGA } & \\
\hline & 0.661 & $(3.4 \mathrm{E}-45)$ & 0.5798 & $(6.2 \mathrm{E}-15)$ & \\
\hline MAP7 & 0.653 & $1.0 \mathrm{E}-43$ & 0.696 & $(<\mathrm{E}-45)$ & $\begin{array}{l}\text { Microtubule-associated proteins, overexpressed } \\
\text { in cytogenetically normal AML patients with } \\
\text { dismal outcomes [32] }\end{array}$ \\
\hline HOPX & 0.619 & $(2.6 \mathrm{E}-38)$ & 0.643 & $(<\mathrm{E}-45)$ & $\begin{array}{l}\text { The smallest homeodomain protein; higher } \\
\text { expression predicts poor prognosis in de novo } \\
\text { AML [33] }\end{array}$ \\
\hline MMRN1 & 0.609 & $(9.7 \mathrm{E}-37)$ & 0.597 & $(<\mathrm{E}-45)$ & $\begin{array}{l}\text { A member of the elastin microfibrillar interface } \\
\text { protein; an adverse marker in both pediatric } \\
\text { and adult AML [34] }\end{array}$ \\
\hline DNMT3B & 0.599 & $(1.7 \mathrm{E}-35)$ & 0.631 & $(<\mathrm{E}-45)$ & $\begin{array}{l}\text { DNA methyltransferases; an important LSC } \\
\text { marker [35-37] }\end{array}$ \\
\hline TCF4 & 0.556 & $(1.1 \mathrm{E}-29)$ & 0.626 & $(<\mathrm{E}-45)$ & $\begin{array}{l}\text { A transcription factor; predict outcome in } \\
\text { RUNX1 mutated and translocated AML [38, } \\
\text { 39] }\end{array}$ \\
\hline SLC38A1 & 0.536 & $(2.3 \mathrm{E}-27)$ & 0.585 & $(<\mathrm{E}-45)$ & $\begin{array}{l}\text { A glutamine amino acid transporter, } \\
\text { overexpressed in AML patients with adverse } \\
\text { clinical outcomes }[40]\end{array}$ \\
\hline DOCK1 & 0.530 & $(1.1 \mathrm{E}-26)$ & 0.597 & $(5.9 \mathrm{E}-16)$ & $\begin{array}{l}\text { A novel class of guanine nucleotide exchange } \\
\text { factors; high expression confers poor } \\
\text { prognosis in AML [41] }\end{array}$ \\
\hline ARHGAP22 & 0.519 & $(1.5 \mathrm{E}-25)$ & 0.518 & $(<\mathrm{E}-45)$ & $\begin{array}{l}\text { Rho GTPase activating protein, incorporated in } \\
\text { the 17-gene LSC score which predicts treat- } \\
\text { ment response in AML [9] }\end{array}$ \\
\hline MN1 & 0.502 & $(1.1 \mathrm{E}-23)$ & 0.565 & $(<\mathrm{E}-45)$ & $\begin{array}{l}\text { A transcriptional coactivator, overexpression } \\
\text { could induce AML in mice and predict ATRA } \\
\text { resistance in human AML patients }[42,43]\end{array}$ \\
\hline$A B C G 1$ & 0.504 & $(6.7 \mathrm{E}-24)$ & 0.610 & $(<\mathrm{E}-45)$ & $\begin{array}{l}\text { Belongs to ATP-binding cassette (ABC) super- } \\
\text { family; responsible for important } \\
\text { chemoresistance mechanism in AML [44-49] }\end{array}$ \\
\hline ABCA2 & 0.367 & $(1.5 \mathrm{E}-12)$ & 0.507 & $(2.3 \mathrm{E}-11)$ & $\begin{array}{l}\text { Belongs to ATP-binding cassette (ABC) super- } \\
\text { family; a strong prognostic biomarker for } \\
\text { multidrug resistance in pediatric acute lym- } \\
\text { phoblastic leukemia [44-49] }\end{array}$ \\
\hline$A B C B 1$ & 0.353 & $(1.2 \mathrm{E}-11)$ & 0.364 & $(5.2 \mathrm{E}-6)$ & $\begin{array}{l}\text { Belongs to ATP-binding cassette (ABC) super- } \\
\text { family; responsible for important } \\
\text { chemoresistance mechanism in AML [44-49] }\end{array}$ \\
\hline$A B C C 1$ & 0.310 & $(3.2 \mathrm{E}-9)$ & 0.458 & (5.2E-9) & $\begin{array}{l}\text { Belongs to ATP-binding cassette (ABC) super- } \\
\text { family; responsible for important } \\
\text { chemoresistance mechanism in AML [44-49] }\end{array}$ \\
\hline
\end{tabular}

could be more strengthened were the expressions of KIAA0125 investigated in AML stem cells and bulk. Despite the limitations mentioned, to the best of our knowledge, this is by far the first study specifically addressing the expression of lncRNA KIAA0125 and its clinical and biological associations in AML patients. We found that higher KIAA0125 expression was closely associated with RUNX1 and DNMT3A1 mutations in both the NTUH and TCGA cohorts. Patients with higher
KIAA0125 expression were more refractory to chemotherapy with a lower CR rate and higher refractory rate (Table 1). They had shorter OS and DFS among the total cohort and subgroups of patients with non-APL and those with normal karyotype. Based on its crucial clinical significance, further experimental studies are necessary to delineate how KIAA0125 participates in the stem cell biology of hematopoietic lineages and its role in the pathogenesis in AML. 
Supplementary Information The online version contains supplementary material available at https://doi.org/10.1007/s00277-020-04358-y.

Acknowledgements We would like to acknowledge the service provided by Department of Laboratory Medicine, Department of Medical Research, and Division of Hematology, Department of Internal Medicine, National Taiwan University Hospital.

Authorship contributions YHW and CCL contribute equally to this study. YHW and CCL were responsible for data collection and management, statistical analysis and interpretation, literature research, and manuscript writing; SYH and CYY were responsible for data management and statistical analysis; CLH assisted in statistical analysis; SHL, CHT, and $\mathrm{HAH}$ were responsible for data collection and management; and WCC and HFT planned, designed, and coordinated the study over the entire period and wrote the manuscript.

Funding The study was supported by grants from Ministry of Health and Welfare, Taiwan (project number: MOHW107-TDU-B-211-114009) and Ministry of Science and Technology, Taiwan (project number: MOST 107-2314-B-002-013 and MOST 108-2314-B-002-011).

Data availability statement The raw and normalized microarray data reported in this article have been deposited in the Gene Expression Omnibus database (accession number GSE68469 and GSE71014).

\section{Compliance with ethical standards}

Conflict of interest The authors declare that they have no relevant competing financial interests.

Informed consent This study was approved by the Research Ethics Committee of NTUH with informed consent obtained from all individual participants included in the study.

Open Access This article is licensed under a Creative Commons Attribution 4.0 International License, which permits use, sharing, adaptation, distribution and reproduction in any medium or format, as long as you give appropriate credit to the original author(s) and the source, provide a link to the Creative Commons licence, and indicate if changes were made. The images or other third party material in this article are included in the article's Creative Commons licence, unless indicated otherwise in a credit line to the material. If material is not included in the article's Creative Commons licence and your intended use is not permitted by statutory regulation or exceeds the permitted use, you will need to obtain permission directly from the copyright holder. To view a copy of this licence, visit http://creativecommons.org/licenses/by/4.0/.

\section{References}

1. Fatica A, Bozzoni I (2014) Long non-coding RNAs: new players in cell differentiation and development. Nat Rev Genet 15(1):7-21. https://doi.org/10.1038/nrg3606

2. Wilusz JE, Sunwoo H, Spector DL (2009) Long noncoding RNAs: functional surprises from the RNA world. Genes Dev 23(13):1494 1504. https://doi.org/10.1101/gad.1800909

3. Kung JT, Colognori D, Lee JT (2013) Long noncoding RNAs: past, present, and future. Genetics 193(3):651-669. https://doi.org/10. 1534/genetics.112.146704
4. Mercer TR, Dinger ME, Mattick JS (2009) Long non-coding RNAs: insights into functions. Nat Rev Genet 10(3):155-159. https://doi.org/10.1038/nrg2521

5. Lin C, Yang L (2018) Long noncoding RNA in Cancer: wiring signaling circuitry. Trends Cell Biol 28(4):287-301. https://doi. org/10.1016/j.tcb.2017.11.008

6. Prensner JR, Chinnaiyan AM (2011) The emergence of lncRNAs in cancer biology. Cancer discovery 1(5):391-407. https://doi.org/10. 1158/2159-8290.Cd-11-0209

7. Huarte M (2015) The emerging role of lncRNAs in cancer. Nat Med 21(11):1253-1261. https://doi.org/10.1038/nm.3981

8. Cheetham SW, Gruhl F, Mattick JS, Dinger ME (2013) Long noncoding RNAs and the genetics of cancer. Br J Cancer 108(12): 2419-2425. https://doi.org/10.1038/bjc.2013.233

9. Alvarez-Dominguez JR, Lodish HF (2017) Emerging mechanisms of long noncoding RNA function during normal and malignant hematopoiesis. Blood 130(18):1965-1975. https://doi.org/10. 1182/blood-2017-06-788695

10. De Clara E, Gourvest M, Ma H, Vergez F, Tosolini M, Dejean S et al (2017) Long non-coding RNA expression profile in cytogenetically normal acute myeloid leukemia identifies a distinct signature and a new biomarker in NPM1-mutated patients. Haematologica 102(10):1718-1726. https://doi.org/10.3324/ haematol.2017.171645

11. Papaioannou D, Nicolet D, Volinia S, Mrózek K, Yan P, Bundschuh R, Carroll AJ, Kohlschmidt J, Blum W, Powell BL, Uy GL, Kolitz JE, Wang ES, Eisfeld AK, Orwick SJ, Lucas DM, Caligiuri MA, Stone RM, Byrd JC, Garzon R, Bloomfield CD (2017) Prognostic and biologic significance of long non-coding RNA profiling in younger adults with cytogenetically normal acute myeloid leukemia. Haematologica 102(8):1391-1400. https://doi. org/10.3324/haematol.2017.166215

12. Schwarzer A, Emmrich S, Schmidt F, Beck D, Ng M, Reimer C, Adams FF, Grasedieck S, Witte D, Käbler S, Wong JWH, Shah A, Huang Y, Jammal R, Maroz A, Jongen-Lavrencic M, Schambach A, Kuchenbauer F, Pimanda JE, Reinhardt D, Heckl D, Klusmann JH (2017) The non-coding RNA landscape of human hematopoiesis and leukemia. Nat Commun 8(1):218. https://doi.org/10.1038/ s41467-017-00212-4

13. Garzon R, Volinia S, Papaioannou D, Nicolet D, Kohlschmidt J, Yan PS, Mrózek K, Bucci D, Carroll AJ, Baer MR, Wetzler M, Carter TH, Powell BL, Kolitz JE, Moore JO, Eisfeld AK, Blachly JS, Blum W, Caligiuri MA, Stone RM, Marcucci G, Croce CM, Byrd JC, Bloomfield CD (2014) Expression and prognostic impact of lncRNAs in acute myeloid leukemia. Proc Natl Acad Sci U S A 111(52):18679-18684. https://doi.org/10.1073/pnas.1422050112

14. Smith JL, Ries RE, Farrar JE, Alonzo TA, Gerbing RB, Leonti AR et al (2019) Long non-coding RNAs (IncRNAs) are highly associated with disease characteristics and outcome in pediatric acute myeloid leukemia - a COG and Tpaml study. Blood 134(Supplement_1):2741. https://doi.org/10.1182/blood-2019127318

15. Pashaiefar H, Izadifard M, Yaghmaie M, Montazeri M, Gheisari E, Ahmadvand M, Momeny M, Ghaffari SH, Kasaeian A, Alimoghaddam K, Ghavamzadeh A (2018) Low expression of long noncoding RNA IRAIN is associated with poor prognosis in nonM3 acute myeloid leukemia patients. Genet Test Mol Biomarkers 22(5):288-294. https://doi.org/10.1089/gtmb.2017.0281

16. Fernando TR, Contreras JR, Zampini M, Rodriguez-Malave NI, Alberti MO, Anguiano J, Tran TM, Palanichamy JK, Gajeton J, Ung NM, Aros CJ, Waters EV, Casero D, Basso G, Pigazzi M, Rao DS (2017) The lncRNA CASC15 regulates SOX4 expression in RUNX1-rearranged acute leukemia. Mol Cancer 16(1):126. https://doi.org/10.1186/s12943-017-0692-x

17. Salehi M, Sharifi M, Bagheri M (2019) Knockdown of long noncoding RNA Plasmacytoma variant translocation 1 with antisense 
locked nucleic acid GapmeRs exerts tumor-suppressive functions in human acute Erythroleukemia cells through Downregulation of CMYC expression. Cancer Biother Radiopharm 34(6):371-379. https://doi.org/10.1089/cbr.2018.2510

18. El-Khazragy N, Elayat W, Matbouly S, Seliman S, Sami A, Safwat $\mathrm{G}$ et al (2019) The prognostic significance of the long non-coding RNAs "CCAT1, PVT1" in $\mathrm{t}(8 ; 21)$ associated acute myeloid leukemia. Gene 707:172-177. https://doi.org/10.1016/j.gene.2019.03. 055

19. Ng SW, Mitchell A, Kennedy JA, Chen WC, McLeod J, Ibrahimova $\mathrm{N}$ et al (2016) A 17-gene stemness score for rapid determination of risk in acute leukaemia. Nature 540(7633):433437. https://doi.org/10.1038/nature20598

20. Metzeler KH, Hummel M, Bloomfield CD, Spiekermann K, Braess J, Sauerland MC, Heinecke A, Radmacher M, Marcucci G, Whitman SP, Maharry K, Paschka P, Larson RA, Berdel WE, Büchner T, Wörmann B, Mansmann U, Hiddemann W, Bohlander SK, Buske C, Cancer and Leukemia Group B, German AML Cooperative Group (2008) An 86-probe-set gene-expression signature predicts survival in cytogenetically normal acute myeloid leukemia. Blood 112(10):4193-4201. https://doi.org/10.1182/ blood-2008-02-134411

21. Chuang MK, Chiu YC, Chou WC, Hou HA, Tseng MH, Kuo YY et al (2015) An mRNA expression signature for prognostication in de novo acute myeloid leukemia patients with normal karyotype. Oncotarget 6(36):39098-39110. https://doi.org/10.18632/ oncotarget.5390

22. Wilop S, Chou WC, Jost E, Crysandt M, Panse J, Chuang MK, Brümmendorf TH, Wagner W, Tien HF, Kharabi Masouleh B (2016) A three-gene expression-based risk score can refine the European LeukemiaNet AML classification. J Hematol Oncol 9(1):78. https://doi.org/10.1186/s13045-016-0308-8

23. Marcucci G, Yan P, Maharry K, Frankhouser D, Nicolet D, Metzeler KH, Kohlschmidt J, Mrózek K, Wu YZ, Bucci D, Curfman JP, Whitman SP, Eisfeld AK, Mendler JH, Schwind S, Becker H, Bär C, Carroll AJ, Baer MR, Wetzler M, Carter TH, Powell BL, Kolitz JE, Byrd JC, Plass C, Garzon R, Caligiuri MA, Stone RM, Volinia S, Bundschuh R, Bloomfield CD (2014) Epigenetics meets genetics in acute myeloid leukemia: clinical impact of a novel seven-gene score. J Clin Oncol 32(6):548-556. https://doi.org/10.1200/jco.2013.50.6337

24. Li Z, Herold T, He C, Valk PJ, Chen P, Jurinovic V et al (2013) Identification of a 24-gene prognostic signature that improves the European LeukemiaNet risk classification of acute myeloid leukemia: an international collaborative study. J Clin Oncol 31(9):11721181. https://doi.org/10.1200/JCO.2012.44.3184

25. Arber DA, Orazi A, Hasserjian R, Thiele J, Borowitz MJ, Le Beau MM et al (2016) The 2016 revision to the World Health Organization classification of myeloid neoplasms and acute leukemia. Blood 127(20):2391-2405. https://doi.org/10.1182/blood2016-03-643544

26. Bennett JM, Catovsky D, Daniel MT, Flandrin G, Galton DA, Gralnick HR et al (1976) Proposals for the classification of the acute leukaemias. French-American-British (FAB) co-operative group. Br J Haematol 33(4):451-458. https://doi.org/10.1111/j.13652141.1976.tb03563.x

27. Tang JL, Hou HA, Chen CY, Liu CY, Chou WC, Tseng MH, Huang CF, Lee FY, Liu MC, Yao M, Huang SY, Ko BS, Hsu SC, Wu SJ, Tsay W, Chen YC, Lin LI, Tien HF (2009) AML1/ RUNX1 mutations in 470 adult patients with de novo acute myeloid leukemia: prognostic implication and interaction with other gene alterations. Blood 114(26):5352-5361

28. Chiu YC, Tsai MH, Chou WC, Liu YC, Kuo YY, Hou HA, Lu TP, Lai LC, Chen Y, Tien HF, Chuang EY (2016) Prognostic significance of NPM1 mutation-modulated microRNA-mRNA regulation in acute myeloid leukemia. Leukemia 30(2):274-284. https://doi. org/10.1038/leu.2015.253

29. Chuang MK, Chiu YC, Chou WC, Hou HA, Chuang EY, Tien HF (2015) A 3-microRNA scoring system for prognostication in de novo acute myeloid leukemia patients. Leukemia 29(5):10511059. https://doi.org/10.1038/leu.2014.333

30. Ley TJ, Miller C, Ding L, Raphael BJ, Mungall AJ, Robertson A et al (2013) Genomic and epigenomic landscapes of adult de novo acute myeloid leukemia. N Engl J Med 368(22):2059-2074. https:// doi.org/10.1056/NEJMoa1301689

31. Chou WC, Chou SC, Liu CY, Chen CY, Hou HA, Kuo YY, Lee MC, Ko BS, Tang JL, Yao M, Tsay W, Wu SJ, Huang SY, Hsu SC, Chen YC, Chang YC, Kuo YY, Kuo KT, Lee FY, Liu MC, Liu CW, Tseng MH, Huang CF, Tien HF (2011) TET2 mutation is an unfavorable prognostic factor in acute myeloid leukemia patients with intermediate-risk cytogenetics. Blood 118(14):3803-3810. https://doi.org/10.1182/blood-2011-02-339747

32. Chou WC, Hou HA, Chen CY, Tang JL, Yao M, Tsay W, Ko BS, Wu SJ, Huang SY, Hsu SC, Chen YC, Huang YN, Chang YC, Lee FY, Liu MC, Liu CW, Tseng MH, Huang CF, Tien HF (2010) Distinct clinical and biologic characteristics in adult acute myeloid leukemia bearing the isocitrate dehydrogenase 1 mutation. Blood 115(14):2749-2754. https://doi.org/10.1182/blood-2009-11253070

33. Chou WC, Huang HH, Hou HA, Chen CY, Tang JL, Yao M, Tsay W, Ko BS, Wu SJ, Huang SY, Hsu SC, Chen YC, Huang YN, Chang YC, Lee FY, Liu MC, Liu CW, Tseng MH, Huang CF, Tien HF (2010) Distinct clinical and biological features of de novo acute myeloid leukemia with additional sex comb-like 1 (ASXL1) mutations. Blood 116(20):4086-4094. https://doi.org/10.1182/ blood-2010-05-283291

34. Hou HA, Lin CC, Chou WC, Liu CY, Chen CY, Tang JL, Lai YJ, Tseng MH, Huang CF, Chiang YC, Lee FY, Kuo YY, Lee MC, Liu MC, Liu CW, Lin LI, Yao M, Huang SY, Ko BS, Hsu SC, Wu SJ, Tsay W, Chen YC, Tien HF (2014) Integration of cytogenetic and molecular alterations in risk stratification of 318 patients with de novo non-M3 acute myeloid leukemia. Leukemia 28(1):50-58. https://doi.org/10.1038/leu.2013.236

35. Grimwade D, Hills RK, Moorman AV, Walker H, Chatters S, Goldstone AH, Wheatley K, Harrison CJ, Burnett AK, on behalf of the National Cancer Research Institute Adult Leukaemia Working Group (2010) Refinement of cytogenetic classification in acute myeloid leukemia: determination of prognostic significance of rare recurring chromosomal abnormalities among 5876 younger adult patients treated in the United Kingdom Medical Research Council trials. Blood 116(3):354-365. https://doi.org/ 10.1182/blood-2009-11-254441

36. Eppert K, Takenaka K, Lechman ER, Waldron L, Nilsson B, van Galen P, Metzeler KH, Poeppl A, Ling V, Beyene J, Canty AJ, Danska JS, Bohlander SK, Buske C, Minden MD, Golub TR, Jurisica I, Ebert BL, Dick JE (2011) Stem cell gene expression programs influence clinical outcome in human leukemia. Nat Med 17(9):1086-1093. https://doi.org/10.1038/nm.2415

37. Ivanova NB, Dimos JT, Schaniel C, Hackney JA, Moore KA, Lemischka IR (2002) A stem cell molecular signature. Science 298(5593):601-604. https://doi.org/10.1126/science.1073823

38. Jaatinen T, Hemmoranta H, Hautaniemi S, Niemi J, Nicorici D, Laine J, Yli-Harja O, Partanen J (2006) Global gene expression profile of human cord blood-derived CD133+ cells. Stem Cells 24(3):631-641. https://doi.org/10.1634/stemcells.2005-0185

39. Xue C, Zhang J, Zhang G, Xue Y, Zhang G, Wu X (2019) Elevated SPINK2 gene expression is a predictor of poor prognosis in acute myeloid leukemia. Oncol Lett 18(3):2877-2884. https://doi.org/10. 3892/ol.2019.10665

40. Elsayed AH, Rafiee R, Cao X, Raimondi S, Downing JR, Ribeiro R, Fan Y, Gruber TA, Baker S, Klco J, Rubnitz JE, Pounds S, 
Lamba JK (2020) A six-gene leukemic stem cell score identifies high risk pediatric acute myeloid leukemia. Leukemia 34(3):735745. https://doi.org/10.1038/s41375-019-0604-8

41. Fu L, Fu H, Zhou L, Xu K, Pang Y, Hu K, Wang J, Tian L, Liu Y, Wang J, Jing H, Huang W, Ke X, Shi J (2016) High expression of MAP7 predicts adverse prognosis in young patients with cytogenetically normal acute myeloid leukemia. Sci Rep 6:34546. https:// doi.org/10.1038/srep34546

42. Lin CC, Hsu YC, Li YH, Kuo YY, Hou HA, Lan KH, Chen TC, Tzeng YS, Kuo YY, Kao CJ, Chuang PH, Tseng MH, Chiu YC, Chou WC, Tien HF (2017) Higher HOPX expression is associated with distinct clinical and biological features and predicts poor prognosis in de novo acute myeloid leukemia. Haematologica 102(6): 1044-1053. https://doi.org/10.3324/haematol.2016.161257

43. Laszlo GS, Alonzo TA, Gudgeon CJ, Harrington KH, Gerbing RB, Wang YC, Ries RE, Raimondi SC, Hirsch BA, Gamis AS, Meshinchi S, Walter RB (2015) Multimerin-1 (MMRN1) as novel adverse marker in pediatric acute myeloid leukemia: a report from the Children's oncology group. Clin Cancer Res 21(14):31873195. https://doi.org/10.1158/1078-0432.Ccr-14-2684

44. Hayette S, Thomas X, Jallades L, Chabane K, Charlot C, Tigaud I, Gazzo S, Morisset S, Cornillet-Lefebvre P, Plesa A, Huet S, Renneville A, Salles G, Nicolini FE, Magaud JP, Michallet M (2012) High DNA methyltransferase DNMT3B levels: a poor prognostic marker in acute myeloid leukemia. PLoS One 7(12):e51527. https://doi.org/10.1371/journal.pone.0051527

45. Niederwieser C, Kohlschmidt J, Volinia S, Whitman SP, Metzeler KH, Eisfeld AK, Maharry K, Yan P, Frankhouser D, Becker H, Schwind S, Carroll AJ, Nicolet D, Mendler JH, Curfman JP, Wu YZ, Baer MR, Powell BL, Kolitz JE, Moore JO, Carter TH, Bundschuh R, Larson RA, Stone RM, Mrózek K, Marcucci G, Bloomfield CD (2015) Prognostic and biologic significance of DNMT3B expression in older patients with cytogenetically normal primary acute myeloid leukemia. Leukemia 29(3):567-575. https:// doi.org/10.1038/leu.2014.267

46. Wong KK, Lawrie CH, Green TM (2019) Oncogenic roles and inhibitors of DNMT1, DNMT3A, and DNMT3B in acute myeloid Leukaemia. Biomark Insights 14:1177271919846454. https://doi. org/10.1177/1177271919846454

47. Gerritsen M, Yi G, Tijchon E, Kuster J, Schuringa JJ, Martens JHA, Vellenga E (2019) RUNX1 mutations enhance self-renewal and block granulocytic differentiation in human in vitro models and primary AMLs. Blood Adv 3(3):320-332. https://doi.org/10.1182/ bloodadvances. 2018024422

48. In't Hout FEM, Gerritsen M, Bullinger L, van der Reijden BA, Huls G, Vellenga E et al (2019) Transcription factor 4 (TCF4) expression predicts clinical outcome in RUNX1 mutated and translocated acute myeloid leukemia. Haematologica. 105:e454-e457. https://doi.org/ 10.3324/haematol.2019.232827

49. Li Y, Shao H, Da Z, Pan J, Fu B (2019) High expression of SLC38A1 predicts poor prognosis in patients with de novo acute myeloid leukemia. J Cell Physiol 234(11):20322-20328. https:// doi.org/10.1002/jcp.28632

50. Lee SH, Chiu YC, Li YH, Lin CC, Hou HA, Chou WC et al (2017) High expression of dedicator of cytokinesis 1 (DOCK1) confers poor prognosis in acute myeloid leukemia. Oncotarget 8(42): 72250-72259. https://doi.org/10.18632/oncotarget.19706

51. Heuser M, Argiropoulos B, Kuchenbauer F, Yung E, Piper J, Fung S, Schlenk RF, Dohner K, Hinrichsen T, Rudolph C, Schambach A, Baum C, Schlegelberger B, Dohner H, Ganser A, Humphries RK (2007) MN1 overexpression induces acute myeloid leukemia in mice and predicts ATRA resistance in patients with AML. Blood 110(5):1639-1647. https://doi.org/10.1182/blood-2007-03-080523
52. Heuser M, Yun H, Berg T, Yung E, Argiropoulos B, Kuchenbauer F, Park G, Hamwi I, Palmqvist L, Lai CK, Leung M, Lin G, Chaturvedi A, Thakur BK, Iwasaki M, Bilenky M, Thiessen N, Robertson G, Hirst M, Kent D, Wilson NK, Göttgens B, Eaves C, Cleary ML, Marra M, Ganser A, Humphries RK (2011) Cell of origin in AML: susceptibility to MN1-induced transformation is regulated by the MEIS1/AbdB-like HOX protein complex. Cancer Cell 20(1):39-52. https://doi.org/10.1016/j.ccr.2011.06.020

53. Choi YH, Yu AM (2014) ABC transporters in multidrug resistance and pharmacokinetics, and strategies for drug development. Curr Pharm Des 20(5):793-807. https://doi.org/10.2174/ 138161282005140214165212

54. Dean M (2005) The genetics of ATP-binding cassette transporters. Methods Enzymol 400:409-429. https://doi.org/10.1016/s00766879(05)00024-8

55. Efferth T, Gillet JP, Sauerbrey A, Zintl F, Bertholet V, de Longueville F, Remacle J, Steinbach D (2006) Expression profiling of ATP-binding cassette transporters in childhood T-cell acute lymphoblastic leukemia. Mol Cancer Ther 5(8):1986-1994. https://doi. org/10.1158/1535-7163.Mct-06-0086

56. Marzac C, Garrido E, Tang R, Fava F, Hirsch P, De Benedictis C et al (2011) ATP binding cassette transporters associated with chemoresistance: transcriptional profiling in extreme cohorts and their prognostic impact in a cohort of 281 acute myeloid leukemia patients. Haematologica 96(9):1293-1301. https://doi.org/10.3324/ haematol.2010.031823

57. Vasiliou V, Vasiliou K, Nebert DW (2009) Human ATP-binding cassette (ABC) transporter family. Hum Genomics 3(3):281-290. https://doi.org/10.1186/1479-7364-3-3-281

58. Aberuyi N, Rahgozar S, Khosravi Dehaghi Z, Moafi A, Masotti A, Paolini A (2017) The translational expression of ABCA2 and $\mathrm{ABCA} 3$ is a strong prognostic biomarker for multidrug resistance in pediatric acute lymphoblastic leukemia. Onco Targets Ther 10: 3373-3380. https://doi.org/10.2147/ott.S140488

59. Diniz MG, Franca JA, Vilas-Boas FAS, de Souza FTA, Calin GA, Gomez RS et al (2019) The long noncoding RNA KIAA0125 is upregulated in ameloblastomas. Pathol Res Pract 215(3):466-469. https://doi.org/10.1016/j.prp.2018.12.030

60. Yang Y, Zhao Y, Hu N, Zhao J, Bai Y (2019) lncRNA KIAA0125 functions as a tumor suppressor modulating growth and metastasis of colorectal cancer via Wnt/beta-catenin pathway. Cell Biol Int 43: 1463-1470. https://doi.org/10.1002/cbin.11196

61. Hornung R, Jurinovic V, Batcha AMN, Bamopoulos SA, Rothenberg-Thurley M, Amler S, Sauerland MC, Berdel WE, Wörmann BJ, Bohlander SK, Braess J, Hiddemann W, Lehmann S, Mareschal S, Spiekermann K, Metzeler KH, Herold T, Boulesteix AL (2018) Mediation analysis reveals common mechanisms of RUNX1 point mutations and RUNX1/RUNX1T1 fusions influencing survival of patients with acute myeloid leukemia. Sci Rep 8(1):11293. https://doi.org/10.1038/s41598-018-29593-2

62. Bowers SR, Calero-Nieto FJ, Valeaux S, Fernandez-Fuentes N, Cockerill PN (2010) Runx1 binds as a dimeric complex to overlapping Runx1 sites within a palindromic element in the human GMCSF enhancer. Nucleic Acids Res 38(18):6124-6134. https://doi. org/10.1093/nar/gkq356

63. Lin C-C, Yao C-Y, Hsu Y-C, Hou H-A, Yuan C-T, Li Y-H, Kao CJ, Chuang PH, Chiu YC, Chen Y, Chou WC, Tien HF (2020) Knock-out of Hopx disrupts stemness and quiescence of hematopoietic stem cells in mice. Oncogene 39(28):5112-5123. https:// doi.org/10.1038/s41388-020-1340-2

Publisher's note Springer Nature remains neutral with regard to jurisdictional claims in published maps and institutional affiliations. 